\title{
Korea's Experiences with Development: Revisiting MDGs from a Time Perspective
}

\author{
Tobin Im* and JungHo Park**
}

\begin{abstract}
As interest in Millennium Development Goals surges, criticism targeting their applicability to developing and underdeveloped countries has also sharply increased. While Millennium Development Goals highlight important development goals, targets, and indices, they lack a time perspective. Korea's experience suggests that it is impractical to pursue all developmental goals simultaneously. Instead, prioritizing goals based on country-specific contexts and approaching them sequentially is an approach better suited to underdeveloped and developing countries, because of their limited resources and underdeveloped social conditions, and can be more effective in achieving multiple goals in the long term.
\end{abstract}

Keywords: development strategy, policy goals, time perspective, Millennium Development Goals

\section{THE MILLENIUM DEVELOPMENT GOALS AND THEIR LIMITS}

During the United Nations Millennium Summit in 2000, 147 heads of state met to discuss the most pressing problems facing humanity. This discussion resulted in the adoption of the Millennium Development Goals (MDGs). To help objectify these goals and underscore commitment to them, quantitative targets were agreed upon and a deadline of 2015 was set for their achievement.

\footnotetext{
* Tobin Im is a professor in the Graduate School of Public Administration, Seoul National University. His teaching and research focus is on organizations, performance management, and comparative administration. He is currently researching the implications of time in these areas. E-mail: tobin@snu.ac.kr.

** JungHo Park is a PhD candidate in the Graduate School of Public and International Affairs, University of Pittsburgh. His research interests are public service motivation (PSM), organizational behavior, comparative public management, and performance management. E-mail: jup22@pitt.edu.
}

Manuscript received October 10, 2010; out for review October 21, 2010; review completed December 6, 2010; accepted December 14, 2010.

The Korean Journal of Policy Studies, Vol. 25, No. 3 (2010), pp. 125-145.

(C) 2010 by the GSPA, Seoul National University 
The MDGs broke new ground in four ways (Fukuda-Parr 2004): First, they were generated by an unprecedented assembly of the world's heads of state. Second, they put human development issues, such as poverty and livelihoods, at the center of the global development agenda - a shift from the economic-oriented growth that is often treated as the only objective of development. Third, they do not just express aspirations but also provide a framework for accountability with concrete goals and targets. Fourth, they incorporate not only developmental outcomes in aid recipient countries but also inputs from donor countries, thus holding both the rich and poor countries accountable in terms of opening markets, giving more aid and debt relief, and transferring technology. The MDGs and their targets are summarized in table 1.

Table 1. M illennium Development Goals and Targets

\begin{tabular}{|c|c|}
\hline Goal & Targets \\
\hline $\begin{array}{l}\text { Goal 1: Eradicate extreme poverty } \\
\text { and hunger. }\end{array}$ & $\begin{array}{l}\text { - Reduce by half the proportion of people living on less than } \$ 1 \text { a day. } \\
\text {-Achieve full and productive employment and decent w ork for all, } \\
\text { including women and young people. } \\
\text { - Reduce by half the proportion of people who suffer from hunger. }\end{array}$ \\
\hline $\begin{array}{l}\text { Goal 2: Achieve universal primary } \\
\text { education. }\end{array}$ & $\begin{array}{l}\text { - Ensure that all boys and girls complete a full course of primary } \\
\text { schooling. }\end{array}$ \\
\hline $\begin{array}{l}\text { Goal 3: Promote gender equality } \\
\text { and empower women. }\end{array}$ & - Eliminate gender disparity in primary and secondary education. \\
\hline Goal 4: Reduce child mortality rates. & - Reduce by two thirds the mortality rate among children under five. \\
\hline Goal 5: Improve maternal health. & $\begin{array}{l}\text { - Reduce by three quarters the maternal mortality ratio. } \\
\text { - Achieve, by } 2015 \text {, universal access to reproductive health services. }\end{array}$ \\
\hline $\begin{array}{l}\text { Goal 6: Combat HIV/AIDS, malaria, } \\
\text { and other diseases. }\end{array}$ & $\begin{array}{l}\text { - Halt and begin to reverse the spread of HIV/AIDS. } \\
\text { - Achieve universal access to HIV/AIDS treatment for those in need } \\
\text { of it by } 2010 \text {. } \\
\text { - Halt and begin to reverse the incidence of malaria and other major } \\
\text { diseases. }\end{array}$ \\
\hline $\begin{array}{l}\text { Goal 7: Ensure environmental } \\
\text { sustainability. }\end{array}$ & $\begin{array}{l}\text { - Integrate the principles of sustainable development into country } \\
\text { policies and programs; reverse the loss of environmental resources. } \\
\text { - Reduce biodiversity loss, achieving by } 2010 \text { a significant reduction } \\
\text { in the rate of loss. } \\
\text { - Reduce by half the proportion of people without sustainable access } \\
\text { to safe drinking water and basic sanitation. } \\
\text { - Achieve a significant improvement in the lives of at least } 100 \text { million } \\
\text { slum dw ellers by } 2020 \text {. }\end{array}$ \\
\hline
\end{tabular}




\begin{tabular}{l|l}
\hline \multicolumn{1}{c|}{ Goal } & \multicolumn{1}{c}{ Targets } \\
\hline $\begin{array}{l}\text { Goal 8: Develop a global partnership } \\
\text { for development. }\end{array}$ & • Further develop an open, rule-based, predictable, nondiscriminatory \\
trading and financial system. \\
• Address the special needs of the least developed countries. \\
• Address the special needs of landlocked developing countries and \\
small island developing states. \\
• Deal comprehensively with the debt problems of developing \\
countries through national and international measures in order to \\
make debt sustainable in the long term. \\
• In cooperation with pharmaceutical companies, provide access to \\
affordable, essential drugs in developing countries. \\
• In cooperation with the private sector, make available the benefits \\
of new technologies, especially information and communications. \\
\hline
\end{tabular}

Source: UNDP n.d.

As table 1 shows, MDGs span a wide range of topics. They are becoming increasingly important, not just within the United Nations but within the larger global development effort. As Jeffrey Sachs said, "To the extent that there are any international goals, they are the Millennium Development Goals" (Attaran 2005).

The concreteness of the MDGs is what makes them attractive. For example, the goal of eradicating extreme poverty includes the concrete target of reducing the proportion of people living on less than a dollar a day by half between 1990 and 2015 . This target in turn consists of a variety of indicators, such as a measure of income based purchasing power. Thus, 28 percent of people around the globe in 1990 had a purchasing power of less than a dollar a day. In order to meet the MDG on poverty reduction, fewer than 14 percent of people should be living on less than a dollar a day by 2015. Based on recent reports, developing countries in East Asia are on track to meet this MDG, while those in sub-Saharan Africa are not. As can be seen from this example, MDGs serve as a useful tool for evaluating progress toward development and indicating areas where greater efforts are needed.

The merits of MDGs can be further recognized when applying theoretical insights from goal theory, which argues that clear, specific, measurable, challenging, and timetargeted objectives can serve as a strong motivational factor in altering the direction of activities. Goal theory suggests that concrete goals and targets are an efficient and effective tool for progress as they ensure that common goals and expectations are clearly established in order for the objectives to be achieved (Tubbs and Ekeberg 1991; Locke 1996; Chun and Rainey 2005).

However, despite their merits, the MDGs fall short of perfection because they do not integrate important temporal aspects of development into their framework. The 
MDGs appear desirable and good natured, which makes critics hesitant to offer substantive scrutiny (James 2006). Thus, while MDGs are very useful, they are often too simplistic and consequently possess considerable limitations. A prime example of this is that some of the goals and indicators used in the framework do not take into account the disparate developmental priorities of different countries, and also neglect the temporal dimensions of the policies. This article addresses these issues by revisiting the MDGs from a time perspective and suggesting possible improvements based on lessons learned from Korean experiences with development.

\section{THE TEMPORAL SIGNIFICANCE OF THE KOREAN EXPERIENCE}

A vital, pervasive, but often neglected dimension in developmental policy making and management is time (Im 2010; Im and Cho 2010; Pollitt 2009). All human activity takes place at a certain point in time, and developmental programs are no exception. Broadly, time is defined as a concept that includes intervals between events, their sequence, duration, and many other factors. The development programs of developing nations should not be disconnected from their past, as ignoring the historically grounded structural and institutional features of a nation may cause reform efforts to fail. The wrong timing or sequencing of developmental programs may create adverse effects.

Hence, an appropriate consideration of the temporal dimension stands to tremendously increase development policy effectiveness, just as some programs have failed because of their lack of time considerations (Choi 2003; Chung 2002). When the temporal context of development is ignored, inaccurate, exaggerated, and superficial prescriptions are likely to result in the countries that require fast and efficient actions the most (Im 2007; Pollitt 2009). Therefore, despite the absolute value of development efforts, the wrong timing or inappropriate ordering of reforms in developing nations is likely to foster negative consequences. Part of the reason for this is that mistiming or improper sequencing of development policies is likely to negatively affect the restructuring of resource distribution and consumption levels in developing nations.

After liberation from Japanese colonial rule in 1945, the Korean masses struggled to overcome an extremely high level of poverty, with a GNP per capita of less than $\$ 100$. By the outbreak of the Korean War in 1948, a majority of Koreans were suffering from malnutrition, and while the subsequent truce brought about a less violent environment, South Korea, badly damaged, appeared to have little hope.

Despite this bleak outlook, rapid economic growth soon ensued and continued for nearly 50 years, with the nation ultimately becoming an OECD member in 1996. The GDP (gross domestic product) rose from $\$ 1.3$ billion in 1953 to $\$ 970$ billion dollars in 
Figure 1. GDP and GNI per Capita from 1953 in Korea

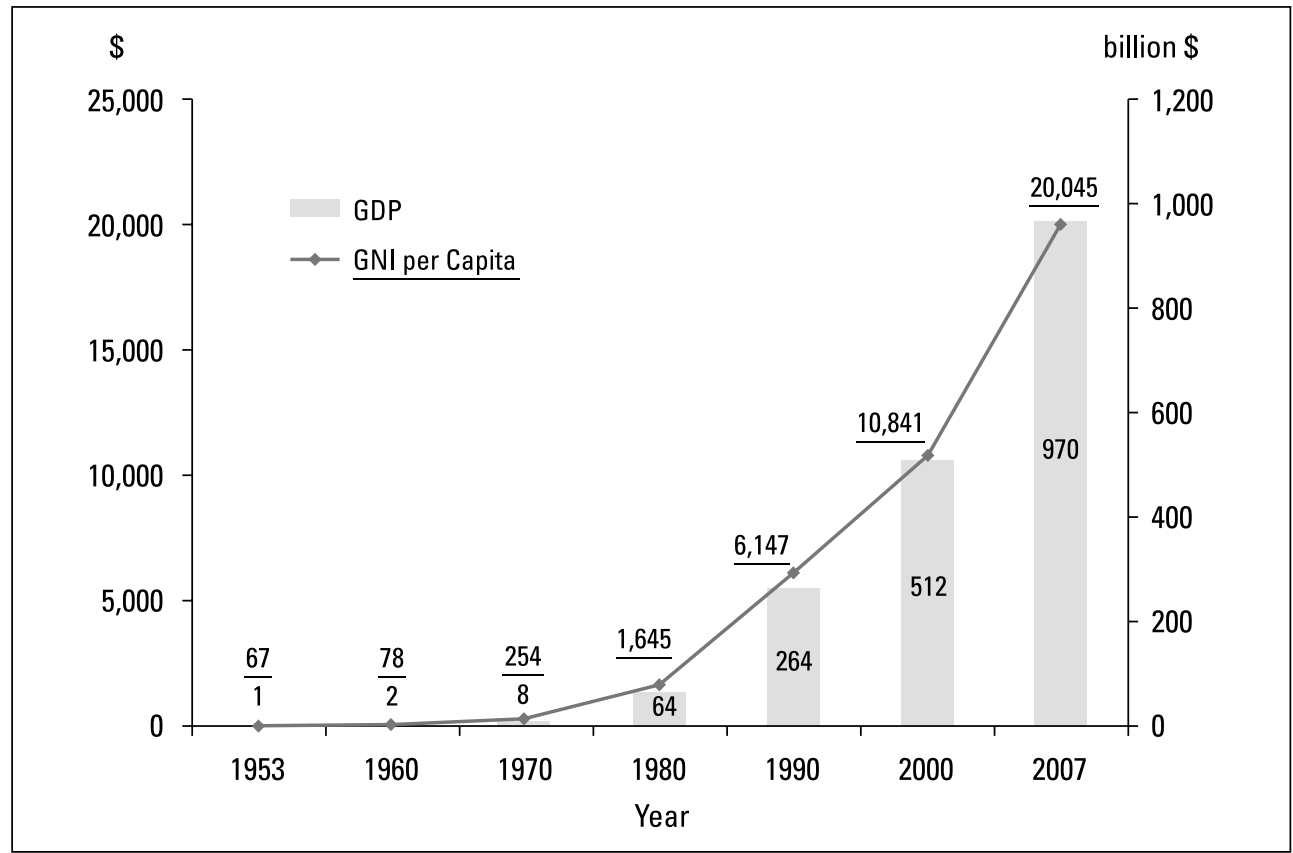

Source: Korea National Statistics Office

Table 2. Korea's Income Level over 50 Years

\begin{tabular}{|c|c|c|c|}
\hline \multicolumn{2}{|c|}{$\begin{array}{c}\text { GNI per capita } \\
\text { in Korea }\end{array}$} & $\begin{array}{c}\text { World Bank } \\
\text { income category }\end{array}$ & Country examples* \\
\hline 1960s & $79-254$ & \multirow[t]{2}{*}{ Low income } & \multirow{2}{*}{$\begin{array}{l}\text { Afghanistan, Bangladesh, Cambodia, Chad, Ethiopia, Gambia, } \\
\text { Ghana, Kenya, Laos, M ali, M ozambique, M yanmar, Nepal, } \\
\text { Rwanda, Somalia, Tajikistan, Tanzania, Togo, Uganda, } \\
\text { Zambia, Zimbabwe }\end{array}$} \\
\hline \multirow[t]{2}{*}{ 1970s } & \multirow[t]{2}{*}{$254-1,645$} & & \\
\hline & & Lower middle & Angola, Bolivia, Cameroon, China, Ecuador, Egypt, Honduras, \\
\hline \multirow[t]{2}{*}{ 1980s } & \multirow[t]{2}{*}{$1,646-6,147$} & income & $\begin{array}{l}\text { India, Indonesia, Iraq, M ongolia, M orocco, Nigeria, Pakistan, } \\
\text { Paraguay, Philippines, Senegal, Sri Lanka, Thailand, } \\
\text { Turkmenistan, Ukraine, Vietnam, Yemen }\end{array}$ \\
\hline & & \multirow{2}{*}{$\begin{array}{l}\text { Upper middle } \\
\text { income }\end{array}$} & \multirow{2}{*}{$\begin{array}{l}\text { Argentina, Belarus, B razil, Bulgaria, Chile, Colombia, Cuba, } \\
\text { Gabon, Iran, J amaica, Kazakhstan, Lebanon, Libya, M alaysia, } \\
\text { M exico, Peru, Romania, Russia, Turkey, Uruguay, Venezuela }\end{array}$} \\
\hline 1990s & $6,148-10,841$ & & \\
\hline $2000 \mathrm{~s}$ & $10,842-20,045$ & High Income & $\begin{array}{l}\text { Australia, Austria, Belgium, Canada, Denmark, Finland, France, } \\
\text { Germany, Greece, Italy, J apan, Korea, N etherlands, } \\
\text { New Zealand, Norway, Poland, Portugal, Spain, Sweden, } \\
\text { Sw itzerland, United Kingdom, United States }\end{array}$ \\
\hline
\end{tabular}

* based on 2009 data 
2007; it reached over $\$ 10$ billion in 1972, $\$ 100$ billion in 1986, and $\$ 500$ billion in 1995. The GDP in 2007 was about 746 times as much as that of 1953. In terms of GNI (gross national income) per capita, the 1953 level of $\$ 67$ increased to over $\$ 1,000$ in $1977, \$ 5,000$ in 1989 , and $\$ 20,045$ in 2007 (see figure 1). Korea has, in roughly 50 years, moved from the lowest income category to the highest (see table 2).

The Korean experience of development has not been limited to economic growth, but has incorporated whole-scale social changes that include nearly every quality-oflife aspect. For example, on the UN's Human Development Index, which measures not only income but also education levels and life expectancy, Korea ranked 26th out of 180 countries in 2009, falling into the "very high human development" category. In specific elements of that index, Korea ranked second in education, third in gross enrollment, 22nd in adult literacy, and 25th in life expectancy. Given Korea's unprecedented success with development, it is possible to draw some lessons for improving global development goals from the Korean case.

\section{METHODOLOGY}

The temporal dimension must be integrated into international development goals, including MDGs. Movements in this direction have already begun and are evidenced by an increased emphasis on the qualitative aspects of development aid allocation, in addition to their quantitative aspects (Thiele et al. 2007). This change in perspective can be attributed to a shift in the mid 1990s that brought widespread pessimism about future contributions of aid because, despite huge expenditures, poverty levels in many developing countries increased, which provoked a steep decline in aid donations.

In an attempt to learn from the mistakes of the past, discussions regarding aid effectiveness have started to argue that the result of development projects can be improved when aid is better targeted to poor recipient countries that have reasonably good local conditions such as basic institutions and economic infrastructure. In other words, for developmental aid to be successful and effectively absorbed in developing nations, certain prerequisites must be fulfilled (Burnside and Dollar 2000; Collier and Dollar 2002). In this respect, the absorption of developmental aid can be linked directly to the temporal characteristic of sequence. Accordingly, questions about the order and duration of policies and projects should be regarded as a fundamental aspect of development.

The MDGs can be seen as challenging and motivational (Bandura and Cervone 1986; Eccles and Wigfield 2002), important aspects of effective goals, according to goal theory. However, goals and targets that are challenging for least developed countries may be much less challenging for middle-income countries. This does not mean 
that the latter have nothing left to strive for, however. Even in high-income countries, development cannot be seen as achieved; rather, such countries must work toward continued development in other domains of quality of life. Thus, development goals for different countries should be pursued only after establishing a proper timeline. This is missing in the MDGs.

This study analyzes development in Korea in an attempt to shed light on how development goals may change over time. However, statistical data as well as other information regarding the development process were not very well documented, and it is difficult to discover what Koreans set as goals, targets, and indicators over the last 60 years. Only in the current decade has international data on development begun to be compiled. Because of the questionable accuracy of a great deal of the statistical data for developing nations, researchers and policy makers have been inclined to limit their focus to what is easily and reliably measurable. This limits decision makers' ability to fully utilize information that is critical for establishing development strategies.

To extract valid information about the history of development in Korea, focus group interviews were used in order to observe open discussion regarding what the Korean government did and how, as well as what was missing in regard to economic and social development. Thirteen government employees who were assumed to have in-depth knowledge of government actions were invited to discuss both documented and undocumented accounts of Korean development, which have been passed on by word of mouth or personally observed (see table 3). They were divided into three discussion groups.

Table 3. Focus Group Interview Participants

\begin{tabular}{l|l|l|l}
\hline Name & Year of birth & \multicolumn{1}{|c}{ Place of work } & Gender \\
\hline Kim & 1984 & Central Officials Training Institute & Male \\
\hline M oon & 1981 & Central Officials Training Institute & Female \\
\hline Park & 1982 & Korea District Heating Corporation & Female \\
\hline J ung & 1975 & Blue House & Male \\
\hline Choi & 1966 & M inistry of Unification & Male \\
\hline Lee & 1976 & M inistry of Public Administration and Security & Male \\
\hline Park & 1976 & National Emergency M anagement Agency & Male \\
\hline Choi & 1969 & Ministry of National Defense & Male \\
\hline Kim & 1962 & Korean Food and Drug Administration & Female \\
\hline Seo & 1973 & Office of the President & Male \\
\hline Yuon & 1980 & National Human Rights Commission & Female \\
\hline Chun & 1971 & Prime M inister's Office & Male \\
\hline Lee & 1982 & Ministry of Public Administration and Security & Male \\
\hline
\end{tabular}


Second, in-depth interviews were conducted with Korean citizens who were born in the 1940s and 1950s and who were able to recall the era of economic development (see table 4). Interviews were composed of semistructured questions regarding how these citizens perceived their needs were met or not met through government actions or international aid.

Table 4. In-Depth Interview Participants

\begin{tabular}{l|c|l|l|l|l}
\hline Name & Year of birth & \multicolumn{1}{|c|}{ Education } & Income level & Occupation & Gender \\
\hline Kim & 1944 & Elementary school dropout & Low & Self-employed & Female \\
\hline Lee & 1939 & College graduate & Middle & Teacher & Male \\
\hline Yoo & 1956 & College graduate & Middle & Homemaker & Female \\
\hline Hyun & 1959 & College graduate & Middle & Homemaker & Female \\
\hline Cho & 1955 & College graduate & Middle & Teacher & Male \\
\hline Chang & 1956 & High school graduate & Middle & Homemaker & Female \\
\hline Choi & 1953 & College graduate & Low & Teacher & Female \\
\hline Cha & 1940 s & High school graduate & Middle & Accountant & Female \\
\hline
\end{tabular}

Third, because an analytical point of view on what has happened so far is needed, an expert on government programs during the Korean development period was interviewed. A retired professor of public administration, he was born in 1933 and was directly involved in a famous Korean rural development project, the Saemaul (new town) movement. Finally, to secure fact-based analysis based on objective written information, official texts of speeches by Korean presidents, including inaugural addresses, were analyzed, focusing on the goals and targets of the Korean government in 10-year intervals in four categories: food, health, and living; economy and industry; environment and culture; and education.

\section{RESULTS AND DISCUSSION}

Using the methods described above, we extracted goals and targets of the Korean government during each period with the intention of comparing them to those found in the MDGs. This new category of time-oriented indicators is of particular interest for under-developed nations around the globe if we assume the universality of the development path. Korea's goals and targets changed from one period to the next, as described in table 5 . 
Table 5. Korea's Development Goals, Targets, and Indicators

\begin{tabular}{|c|c|c|c|c|}
\hline Category & $\begin{array}{l}\text { Food, health, and living } \\
\text { (M DGs 4,5,6) }\end{array}$ & $\begin{array}{c}\text { Economy and industry } \\
\text { (MDGs 1,3) }\end{array}$ & $\begin{array}{c}\text { Environment and culture } \\
\text { (M DG 7) }\end{array}$ & $\begin{array}{l}\text { Education } \\
\text { (MDG 2) }\end{array}$ \\
\hline \multicolumn{5}{|c|}{$1960 \mathrm{~s}$} \\
\hline Goals & $\begin{array}{l}\text { End hunger. } \\
\text { Prevent epidemics. }\end{array}$ & $\begin{array}{l}\text { M obilize workforce. } \\
\text { Increase incomes. }\end{array}$ & None & $\begin{array}{l}\text { Bring children to } \\
\text { school. }\end{array}$ \\
\hline Targets & $\begin{array}{l}\text { Distribution of food, } \\
\text { milk, and insecticides; } \\
\text { disinfecting activities; } \\
\text { access to basic } \\
\text { healthcare; family } \\
\text { planning }\end{array}$ & $\begin{array}{l}\text { Women's economic } \\
\text { activity, mobilization of } \\
\text { labor in agricultural off- } \\
\text { season; investment in } \\
\text { industries like fertilizer } \\
\text { and cement }\end{array}$ & None & $\begin{array}{l}\text { Establishing } \\
\text { elementary schools; } \\
\text { classroom } \\
\text { construction }\end{array}$ \\
\hline Indicators & $\begin{array}{l}\text { Infant mortality rate; } \\
\text { number of deaths from } \\
\text { epidemics }\end{array}$ & $\begin{array}{l}\text { Employment rate; } \\
\text { women's employment } \\
\text { rate }\end{array}$ & None & $\begin{array}{l}\text { Number of schools; } \\
\text { enrollment in primary } \\
\text { schools }\end{array}$ \\
\hline \multicolumn{5}{|c|}{ 1970s } \\
\hline Goals & $\begin{array}{l}\text { Increase crop } \\
\text { production. } \\
\text { Prevent diseases. } \\
\text { Provide basic living } \\
\text { environment. }\end{array}$ & $\begin{array}{l}\text { Develop industry. } \\
\text { Construct basic } \\
\text { infrastructure for } \\
\text { economic } \\
\text { development. }\end{array}$ & Little attention & $\begin{array}{l}\text { elite education. } \\
\text { Produce educated } \\
\text { workforce. }\end{array}$ \\
\hline Targets & $\begin{array}{l}\text { Fertilizer provision; } \\
\text { increased production } \\
\text { of rice; vaccinations; } \\
\text { rest room and roof } \\
\text { improvements }\end{array}$ & $\begin{array}{l}\text { Industrial clustering; } \\
\text { readjustment of } \\
\text { agricultural and } \\
\text { riverside land; } \\
\text { construction of roads, } \\
\text { highways, and dams }\end{array}$ & $\begin{array}{l}\text { Little activity for culture } \\
\text { and leisure; some } \\
\text { forestation, but little } \\
\text { attention to } \\
\text { environmental pollution }\end{array}$ & $\begin{array}{l}\text { Building good schools; } \\
\text { more vocational high } \\
\text { schools; preferential } \\
\text { treatment for teachers }\end{array}$ \\
\hline Indicators & $\begin{array}{l}\text { Crop production per } \\
\text { acre; immunization } \\
\text { rate; medical facilities } \\
\text { per capita; rate of } \\
\text { modernized housing }\end{array}$ & $\begin{array}{l}\text { Amount of exports; } \\
\text { level of industrial } \\
\text { resource availability; } \\
\text { pavement rate for } \\
\text { roads; length of } \\
\text { highways }\end{array}$ & $\begin{array}{l}\text { Size of green areas per } \\
\text { unit area, number of } \\
\text { trees planted }\end{array}$ & $\begin{array}{l}\text { Test scores; higher } \\
\text { education rates; } \\
\text { graduation rates }\end{array}$ \\
\hline \multicolumn{5}{|c|}{ 1980s } \\
\hline Goals & $\begin{array}{l}\text { Improve living } \\
\text { environment. }\end{array}$ & $\begin{array}{l}\text { Stabilize prices and } \\
\text { labor market. }\end{array}$ & basic cultural facilities. & $\begin{array}{l}\text { Improve educational } \\
\text { infrastructure. }\end{array}$ \\
\hline Targets & $\begin{array}{l}\text { Water supply facilities } \\
\text { and drainage; power } \\
\text { supply; modern house } \\
\text { construction }\end{array}$ & $\begin{array}{l}\text { Wage-freeze policy; } \\
\text { government spending } \\
\text { freeze }\end{array}$ & $\begin{array}{l}\text { Artmuseums; other } \\
\text { museums, concert halls }\end{array}$ & $\begin{array}{l}\text { Improved school } \\
\text { facilities and } \\
\text { equipment }\end{array}$ \\
\hline
\end{tabular}




\begin{tabular}{|c|c|c|c|c|}
\hline Category & $\begin{array}{l}\text { Food, health, and living } \\
\text { (M DGs 4,5,6) }\end{array}$ & $\begin{array}{c}\text { Economy and industry } \\
\text { (MDGs } 1,3)\end{array}$ & $\begin{array}{l}\text { Environment and culture } \\
\text { (MDG 7) }\end{array}$ & $\begin{array}{l}\text { Education } \\
\text { (MDG 2) }\end{array}$ \\
\hline Indicators & $\begin{array}{l}\text { Water and drainage } \\
\text { supply rate; power } \\
\text { supply rate; telephone } \\
\text { line lengths }\end{array}$ & $\begin{array}{l}\text { Purchasing power; } \\
\text { consumer price index; } \\
\text { living necessaries } \\
\text { index }\end{array}$ & $\begin{array}{l}\text { Number of museums, } \\
\text { libraries, and other } \\
\text { cultural facilities }\end{array}$ & $\begin{array}{l}\text { Number of students } \\
\text { per class; amount of } \\
\text { school land per } \\
\text { student; distance } \\
\text { from school }\end{array}$ \\
\hline \multicolumn{5}{|c|}{ 1990s } \\
\hline Goals & $\begin{array}{l}\text { Care for the } \\
\text { underprivileged } \\
\text { population. }\end{array}$ & $\begin{array}{l}\text { Modernize industry. } \\
\text { Distribute wealth more } \\
\text { equitably. }\end{array}$ & $\begin{array}{l}\text { Regulate environmental } \\
\text { pollution. }\end{array}$ & $\begin{array}{l}\text { Improve educational } \\
\text { quality. } \\
\text { Promote equality. }\end{array}$ \\
\hline Targets & $\begin{array}{l}\text { Sheltered housing for } \\
\text { the handicapped and } \\
\text { the aged; medical } \\
\text { support for the needy }\end{array}$ & \begin{tabular}{|l|} 
Support for service \\
industry; subsidy of \\
information technology \\
industry; cultural \\
industry; airport \\
construction
\end{tabular} & $\begin{array}{l}\text { Volume-rate garbage } \\
\text { disposal system; levy } \\
\text { for emitting pollutants; } \\
\text { separate garbage } \\
\text { collection }\end{array}$ & $\begin{array}{l}\text { Reduce private } \\
\text { education; air } \\
\text { conditioning; regional } \\
\text { balancing }\end{array}$ \\
\hline Indicators & $\begin{array}{l}\text { Number of shelter } \\
\text { facilities }\end{array}$ & $\begin{array}{l}\text { Income distribution } \\
\text { rate, gini }\end{array}$ & $\begin{array}{l}\text { Per capita } \mathrm{CO}_{2} \\
\text { emissions }\end{array}$ & $\begin{array}{l}\text { Number of } \\
\text { playgrounds per } \\
\text { student }\end{array}$ \\
\hline \multicolumn{5}{|c|}{$2000 \mathrm{~s}$} \\
\hline Goals & $\begin{array}{l}\text { Provide enhanced } \\
\text { standards of living. } \\
\text { City design. }\end{array}$ & \begin{tabular}{|l|} 
Provide satisfaction \\
with economic life. \\
Promote green growth.
\end{tabular} & $\begin{array}{l}\text { cultural event. } \\
\text { Restore the destroyed } \\
\text { environment. }\end{array}$ & $\begin{array}{l}\text { Reduce excessive } \\
\text { competition, } \\
\text { diversification. }\end{array}$ \\
\hline Targets & $\begin{array}{l}\text { Chemical-free food } \\
\text { production certific ation; } \\
\text { designing city; } \\
\text { installation of safe } \\
\text { doors in subways }\end{array}$ & $\begin{array}{l}\text { Set up fair market } \\
\text { competition. } \\
\text { Privatization. } \\
\text { Provide job } \\
\text { opportunities for senior } \\
\text { citizens. }\end{array}$ & $\begin{array}{l}\text { Promote regional } \\
\text { festivals and } \\
\text { exhibitions. } \\
\text { Eco-friendly river } \\
\text { arrangement. } \\
\text { Provide sports facilities } \\
\text { and bicycle paths. }\end{array}$ & $\begin{array}{l}\text { Provide diverse } \\
\text { activities for students' } \\
\text { leisure time. }\end{array}$ \\
\hline Indicators & $\begin{array}{l}\text { Urban population rate; } \\
\text { city landscape }\end{array}$ & $\begin{array}{l}\text { Consumption; working } \\
\text { hours; unemployment } \\
\text { rate }\end{array}$ & $\begin{array}{l}\text { Noise pollution index; } \\
\text { total attendance at } \\
\text { events }\end{array}$ & $\begin{array}{l}\text { Student suic ide rate; } \\
\text { percentage of } \\
\text { students who smoke; } \\
\text { club participation rate }\end{array}$ \\
\hline
\end{tabular}

The government set different policy goals in each time period, mobilizing scarce resources and concentrating on priority sectors efficiently at the appropriate time, thereby greatly contributing to meeting citizens' needs as well as human development needs such as poverty alleviation, economic growth, and education. The following sections discuss these changing development goals in more detail. 


\section{Food, Health, and Living: From Alleviating Hunger to Designing Well-Being}

Developmental goals in the food, health, and housing sectors correspond to MDGs 4, 5, and 6. Shifts in the Korean government's development goals in this sector can be best summarized by the phrase "from satisfying hunger to designing well-being." An article written in 1965 described Korean living conditions at that time as follows:

The lives of the Korean masses, for last 20 years since liberation, have been threatened by starvation: their everyday existence is like flying stunts in a circus. The overwhelming optimism of independence has disappeared, and they are now fighting against hunger. The desire to eat is a basic, fundamental, and biological urge and the most primitive of all levels of human needs.

In the 1960s, the Korean people's needs were basic and urgent and fundamentally revolved around food and survival. One of the most vital government goals of the 1960s was supplying food to children in elementary schools. The Korean government did not have the resources to feed children, but made an effort to distribute food aid donated by the international community to school children efficiently. Thus, children enrolled in school received food aid such as bread made out of corn. The way food aid was distributed in Korea is in stark contrast to the unpleasant situation experienced by some of the least developed countries, where aid is often misused and falls into the hands of dictators or high-level government officials or military groups. The just and efficient distribution of aid can serve as an important catalyst for development in less developed countries.

One of the programs created by the Korean government during this poverty-stricken era was to promote the production and consumption of milk in order to meet basic nutritional needs. As rice was the basic food, few Koreans drank milk before this policy was implemented. While this may seem like a trivial detail in Korea's race to economic development, such ideas were vital to the overall transformation of the poor country. A law was enacted in 1967 to promote the production of milk, which is highly nutritional, and its distribution to undernourished citizens, especially elementary school students. The government established official targets of milk consumption levels, and required nearly all elementary schools to establish a milk supply system that would help children consume milk easily and at a discounted price.

The family planning and birth control policy that began in 1962 also targeted the food supply problem. High birth rates and a preference for male children were endemic to Korean society at this time. Consequently, a campaign was launched to change people's attitudes toward birth and provided government services to parents in an effort to control pregnancy rates, with extremely successful results. The birth rate declined 
sharply from 1970 to 1985: the total fertility rate (children born/woman) was 4.53 in 1970 and 1.26 in 2007, and the crude birth rate (childbirths/1,000 people a year) was 31.2 in 1970 and 10.1 in 2007.

There is no doubt that the family planning policy of the Korean government was effective in solving food supply problems and contributed to the economic development of the country. However, not long after the turn of the 21st century, Korea came to have the lowest birth rate of all OECD members. Now, the low birth rate is causing many social problems, which are expected to spur other serious problems in the near future. The fertility reduction program seems to have lasted too long, and as a result has created a need for programs geared toward increasing fertility rates.

In the 1970s, the Korean government focused on expanding the production of food and other agricultural products, with a representative example being the efforts to improve rice and barley production. Prior to the 1970s, the rate of rice production was less than 300 kilograms per 10 acres, which in aggregate represented around three million tons of food for a country inhabited by thousands of millions of people, according to data from National Institute of Crop Science. In an effort to increase agricultural productivity, the Korean government undertook programs such as establishing national research institutes for crop production and constructing fertilizer plants in the late 1960s and early 1970s. In the 1970s, the institute improved varieties of rice which resulted in an increase in rice production by 1977 to 493 kilograms per 10 acres. By the 1980s, rice supply had surpassed demand, which put Korea in a position of exporter to nations such as Indonesia.

With this basic level of need satisfied for society at large, the Korean government began to pursue different food goals. For example, in the 1990s, the government began to address issues related to nutrition and food availability for the underprivileged population. Additionally, in the late 1990s and 2000s, the so-called well-being movement, which is concerned with safe and healthy foods, was promoted by the government.

To address housing issues, the Korean government initiated the Saemaul movement in the 1970s, which focused on the improvement of living conditions and housing. The traditional style of house, which was still common, particularly in rural areas, was a thatched-roof house with very unsanitary restrooms and poor sanitation. The Saemaul movement aimed to improve these conditions. Along these lines, in the 1980s, the government made an effort to install water supply facilities, provide drainage, and provide power, which contributed to the modernization of houses and living standards.

The government also undertook the construction of large apartment complexes in order to provide modern housing units to larger proportions of the population more effectively. In the 2000s, policies of living and housing were upgraded. People are now more concerned with qualitative changes such as improved design and safety. For 
example, Seoul city and other local governments in Korea have made design and beautification projects a priority. In addition, the government has tried to improve safety by undertaking projects such as installing safer doors in subway stations.

With regards to healthcare, the Korean government during the 1960s attempted to prevent epidemics which, at the time, constituted a serious health threat that could ultimately cause a loss of human capital. To address this issue the government conducted widespread disinfecting activities and also provided access to basic healthcare. In the 1970s, the government pursued widespread vaccination and immunization programs. Issues of equality also rose to the fore in the healthcare sector. Consequently, medical support and healthcare for the needy, the handicapped, and the elderly were established as targets for development. In the 2000s, the well-being trend, as mentioned earlier, was a prime issue. Thus, healthcare goals shifted at the appropriate time from surviving to enjoying a better quality of life, which has further led to campaigns against smoking and the consumption of alcohol.

\section{Economy and Industry: \\ From Eradicating Poverty to Improving the Quality of Life}

Korea's economic development goals progressed from eradicating poverty to qualitative growth, which is comparable to MDGs 1 and 3. Following the three-year Korean civil war in the early 1950s, which destroyed most of the sparse economic infrastructure, hunger and unemployment were widespread. The Korean government, beginning in the 1960s, addressed several critical challenges that were mainly concerned with the pursuit of economic development despite a lack of resources.

During this time, the only resource Korea possessed in abundance was labor, particularly in rural areas. Yet productivity and income levels were extremely low, to the extent that people had trouble sustaining their daily lives. Furthermore, the Korean government lacked sufficient international currency to import raw materials to construct industrial facilities.

In order to break the vicious cycle of economic distress that followed the Korean War, the Korean government asked for financial aid from the international community, including the United States, Japan, and charitable organizations such as World Vision. The Korean government planned to use the aid to mobilize the workforce and spark a shift from a predominantly agricultural economy to an industrial economy. During the 1960 s, the Korean economy still relied heavily on agriculture. The long-term economic development plan of the 1970s sought to use financial aid to fund the manufacturing of cement, which would be used for later investments in infrastructure, and fertilizer, which would increase agricultural productivity. 
During the 1970s, one of the most critical challenges facing Korean society was the lack of transportation and related infrastructure, such as roads and harbors, which sharply increased the cost and time required to transport industrial materials, products, and labor. Thus, another major objective of the Korean government during this era was construction of basic transportation infrastructure that was capable of facilitating economic development.

Poor infrastructure was not the only hurdle for Korean economic development. In this period, economic development in South Korea was led by a small number of private companies that lacked the capacity to stimulate strong national economic growth. The Korean government sought to stimulate the economy by providing the industrial sector with a blueprint for development that included the design of industrial clusters and a system of generous government subsidies. To address issues concerning sufficient labor resources and technological capacity, heavy industry was given priority and supported by the government; areas located near harbors were designated as primary sites of heavy industry.

Promoted by these government initiatives, rapid economic development in both light and heavy industry ensued and sparked an exodus of young adults from rural areas to the industrial and metropolitan areas during the 1980s. It also resulted in a labor shortage in the industrial sector. This means that workers' salaries increased rapidly, which corresponded to a decline of efficiency and productivity in this sector.

Once economic growth reached a certain level, pent-up desires exploded in many areas of society. With basic needs satisfied, many Korean citizens began demanding democratization and greater political rights and freedoms. Beginning in this period of high economic growth, Korean society suffered from political conflicts, especially those initiated by a violent student movement. Nonetheless, the Korean government's economic policy remained consistent, controlling salary increases, stabilizing the labor supply, minimizing government expenditures, and eliminating political conflicts.

From the 1990s, the Korean economy began to transition into high-tech industries by investing in research and development centers, creating new universities, and supporting private high-tech manufacturers. During this period in particular, the role of the Korean government was viewed as being the driving force behind the markets and influencing private corporations to expand into new industrial areas and increase their competitiveness in the global market.

To stimulate the expansion of private corporations into new areas of economic development, the government created a system of sophisticated administrative supports for private companies. Through this active collaboration between the public and the private sectors, the information technology and semiconductor industries were flagged as the most promising fields for further economic growth in Korea. 
At the turn of the 21st century, GDP per capita levels in Korea reached roughly $\$ 20,000$. Resulting from this high level of economic development, other social issues quickly emerged such as quality of life and the balance between environmental protection and industrial development. Thus, the role of government policy makers has had to change significantly. Most notably, there has been ongoing debate about deregulation and about whether it is desirable for the government to continually intervene in private markets and attempt to stimulate economic development.

\section{Environment and Culture: Better Late than Never}

The Korean government's changing development goals in relation to the environment (corresponding to MDG 7) and culture are best summarized by the phrase "from no effort to a belated response." During the 1960s and 1970s, little attention was paid to environmental issues, and there were very few movements that advocated environmental concerns. When environmental issues did make their way onto the policy agenda, it was out of necessity rather than choice. An example of this were the recurring floods that resulted from numerous typhoons during the summer season, which raised the issue of flood prevention. In order to mitigate this natural disaster, the Korean government chose a policy of forestation for the purpose of flood prevention.

Even though the quality of air and water deteriorated throughout the industrialization period, discussion of systematic environmental regulation did not begin until the mid 1980s. Many environmental issues_-garbage disposal, water contamination, and air pollution—emerged as key policy problems during this period. By the 1990s there were strong social demands for environmental protection, most markedly in regard to a movement against constructing a nuclear waste disposal unit, a dam, and a highway that would adversely affect the ecological system. As various social actors (such as nongovernmental and nonprofit organizations and academics) actively participated in the promotion of environmental issues and mobilized political support for environmental protection, the Korean government began to pay more attention to environmental policy. Examples of such initiatives include imposing levies for emitting pollutants, implementing separate garbage collection, and creating a volume-rate garbage disposal system.

In the 2000s, environmental issues and policies were regarded as an even more important pillar of government policy. In particular, prior to a large construction project, the government was obliged to ask neutral experts to evaluate the possible environmental effects. The government also placed a great deal of importance upon restoring damage already done to the environment. This outlook stands in contrast with that of the 1960s, when economic development caused significant environmental damage. 
The Korean government did not and could not pursue the growth of all social and environmental spheres at the same time. Rather, the government prioritized its developmental agenda, flagging economic development as the first goal on the long path toward overall development, due to Korea's limited resources and urgent economic needs. Nonetheless, as the economy, followed by other social spheres, improved sufficiently, priorities shifted toward the protection of the environment. Thus, ultimately the Korean government pursued environmental projects in tandem with other social issues.

Like environmental issues, cultural aspects of citizens' lives were not considered a primary issue in Korean society during the 1960s and 1970s. Many sites with significant cultural and historical value were not well preserved and were neglected in favor of economic growth. Although the Korean government gradually increased its efforts to restore cultural and historical sites, few opportunities existed for the general public to engage in traditional festivals and enjoy the cultural aspects of life in this time period.

These conditions have changed radically since the 1980s. Over the past 30 years, the construction of museums, art galleries, concert halls, and leisure complexes has substantially increased. For example, the number of museums that were constructed from 1997 to 2007 illustrates how rapidly cultural facilities grew in the 1990s and 2000s (see figure 2).

Figure 2. Number of M useums in Korea

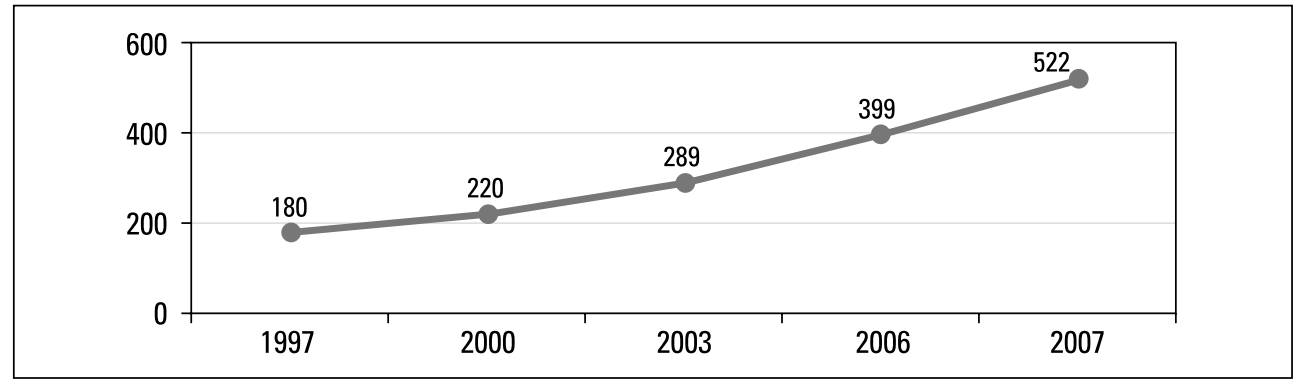

Source: Adapted from data in Yang 2006, p. 9.

In addition, local governments created local festivals based upon cultural traditions; as of 2006, local governments across Korea held a total of 1,176 festivals (MCST 2006). Since the 1980s, increasing income levels and expectations of a better quality of life have steadily expanded the markets related to entertainment and culture. As such, developmental goals in regard to culture had to respond to the increasing demands and consequently led the Korean government to invest in restoring diverse cultural sites and expanding entertainment facilities. 


\section{Education: From Opportunity to Diversity}

The educational aspects of Korea's developmental goals are directly related to MDG 2. Before discussing the governments' education policy, it is important to first address how Korean society views education. Korean parents have traditionally put a great emphasis upon their children's education. Even during the 1960s, when economic conditions were not conducive to education, a majority of parents tended to sacrifice their economic well-being to their children's educational needs. A major reason behind this sacrifice was the pervasive influence on Korean society of Confucian philosophy, which emphasizes learning and education. Also, the rapid economic growth of the country provided ample opportunities for upward mobility in society; parents also strongly believed that education helped children become socially successful.

In the 1960s, the goal of the Korean government was to bring children to schools. Elementary school education was already compulsory in this period of economic misery. Due to the lack of educational facilities and teachers, the government's efforts focused on infrastructure. Other key components of this approach consisted of increasing educational opportunities and further reducing the levels of illiteracy.

In the 1970s, the goal of education was harmonized with other economic policies. As the industrial sector grew rapidly, it required more diverse labor skills, which could only be provided through systematic education. For this purpose, the developmental goal in education was to reform the diverse vocational high schools and colleges in order to reduce the gap between demand for and supply of skilled workers. Furthermore, the curriculum in vocational schools was oriented toward preparing students' technical knowledge and skills (for example, in mechanical, agricultural, and commercial specialties) for their future jobs. During this period, the Korean economy still emphasized heavy industry instead of high-tech technology, and as such the vocational schools played a critical role in providing well-trained workers for the growing companies of that period.

In the 1980s, the developmental goal in education still stressed improvements to educational infrastructure. During this time the average class size was too large to insure the quality of education. Thus, the Korean government extended its investment in infrastructure by constructing more middle and high schools. In addition, government stressed the importance of educational equipment and facilities. In 1984, middle school education became mandatory for all children.

In the 1990s, the goal of the Korean government in the field of education was to advance the quality of education by improving the quality of educators, developing diverse content for educational programs, and improving school equipment. Compared to the goals of 1960s and 1970s, these goals shifted from quantity to quality, 
focusing on diversity of educational programs and students' practical participation in the classroom.

One particularly significant phenomenon during this period was the growing number of high school students who went to college or university. As of 2009, 81.9\% of high school students went to college or university (Statistics Korea 2009). As the number of college graduates increased, more highly educated people were able to participate in diverse fields of the social sphere.

The result of these trends was that by the 2000s, Korea's educational environment was seen by many as overly competitive. This prompted growing criticisms of Korean education due to students' lack of social experiences. Students had little time to pursue any interests outside of school. Additionally, extremely high levels of competition among high school students to win admission to one of the more renowned universities created many social issues that were associated with social polarization, distribution of wealth, and the real meaning of educational equality.

The uniqueness of the Korean experience in the area of education is that the Korean government persistently invested a large proportion of national resources in education, even when its resources were insufficient to feed its own people. In the long run, this contributed to higher levels of human capital. The increasingly educated workforce played a critical role in shifting the industrial characteristics of Korea and promoting the country's social and economic development.

\section{CONCLUSION}

One of the major limitations of the MDGs is that some of the goals and indicators have different levels of importance in different countries at different times. Any government must first attend to the most urgent needs of society, which clearly requires trade-offs whereby other goals and targets, based on a long-term perspective, must be dropped. Thus, developmental policy making and management must take time dimensions into consideration (Im 2010; Im and Cho 2010; Pollitt 2009). All human and social activity is conducted at a certain point in time, and developmental processes are no exception. When there is more than one goal and multiple targets, it may be impossible to achieve all of them at once.

The Korean case has shown that temporal dimensions can be an important factor when a country has limited resources. The way Korea's development goals changed over time suggests some implications for MDGs, in that it is important to understand that different goals may be important during different times in a country's development. Table 6 summarizes changes in Korea's development goals. 
Table 6. Relative Importance of M DGs in the Korean Experience

\begin{tabular}{l|c|l|l|l}
\hline \multicolumn{1}{c|}{ Time period } & \multicolumn{1}{c|}{ 1960s, 1970s } & \multicolumn{1}{c|}{ 1980s } & \multicolumn{1}{c}{ 1990s } & \multicolumn{1}{c}{ 2000s } \\
\hline Income level of South Korea & Low & Lower middle & Upper middle & High \\
\hline M DG 1 (reducing poverty, hunger) & $* * * *$ & $* * *$ & $* *$ & $*$ \\
\hline M DG 2 (education) & $* * * *$ & $* * *$ & $* *$ & $* *$ \\
\hline M DG 3 (gender equality) & - & - & $*$ & $* *$ \\
\hline M DG 4 (reducing child mortality) & $* * *$ & $* *$ & $*$ & $*$ \\
\hline M DG 5 (maternal health) & $* *$ & $* *$ & $*$ & $*$ \\
\hline M DG 6 (reducing disease) & $* * * *$ & $* * *$ & $* *$ & $*$ \\
\hline M DG 7 (environment) & - & - & $*$ & $* *$ \\
\hline M DG 8 (global partnership) & $* *$ & $*$ & $* * *$ & $* * *$ \\
\hline
\end{tabular}

As Table 6 illustrates, Korea experienced a dynamic change of emphasis on development goals over time. We can cautiously provide this timeline as a model for lowincome countries struggling with the social and economic distress associated with the early stages of development. In the beginning, they will likely need to concentrate on economic conditions and infectious disease that can damage society as a whole and halt much economic activity. The eradication of hunger and the establishment of universal education are fundamental starting points for development. In particular, sufficient and persistent investment in education is essential and can create long-term positive effects for society as a whole and for the economy. Increased education levels are likely to broadly benefit the economic, political, and environmental spheres.

The MDGs, with their goals, targets, and indices, can help many countries to examine their social conditions and economic growth strategies. But they do not integrate all important aspects of developmental processes and goals. As James (2006) and Fukuda-Parr (2004) have pointed out, the MDGs, so straightforward and self-evident, and consequently held in high regard by developed and developing countries alike, tend nevertheless to oversimplify the way complex social conditions and problems develop over time. In the worst case, the MDGs can cause wasteful investments of development funds if they are pursued without consideration of their temporal dimensions. The Korean case provides an example of the success that can be achieved when the assumption that all goals are of equal importance and can be pursued simultaneously is abandoned. 


\section{REFERENCES}

Attaran, A. 2005. An immeasurable crisis? A criticism of the Millennium Development Goals and why they cannot be measured. PLoS Medicine 2 (10): 955.

Bandura, A., and D. Cervone. 1986. Differential engagement of self-reactive influences in cognitive motivation. Organizational Behavior and Human Decision Processes 38 (1): 92-113.

Barbara, A. 1994. Time and Social Theory. Cambridge: Polity Press.

Burnside, C., and Dollar, D. 2000. Aid, policies, and growth. American Economic Review 90(4): 847-868.

Choi, J. W. 2003. Time-lag theory and administrative reforms. Korea Public Administration Review 37 (2): 289-305.

Chun, Y., and H. Rainey. 2005. Goal ambiguity and organizational performance in US federal agencies. Journal of Public Administration Research and Theory 15 (4): 529.

Chung, C. K. 2002. Time-lag approach for the study of public administration and policy study: Issues of institutional congruency. Korea Public Administration Review $36(1), 1-19$.

Collier, P., and Dollar, D. 2002. Aid allocation and poverty reduction. European Economic Review 46 (8): 1475-1500.

Duff, M. J., Okun, L. B. and Veneziano, G. 2002. Trialogue on the Number of Fundamental Constants. Journal of High Energy Physics 3 (23): 1-30.

Eccles, J., and A. Wigfield. 2002. Motivational beliefs, values, and goals. Annual review of psychology: 109-133.

Fukuda-Parr, S. 2004. Millennium development goals: Why they matter. Global Governance 10 (4): 395-403.

Im, T. 2007. Bureaucracy, Democracy and Market: Critique on 20 years' Government Reforms in Korea. The Korean Journal of Public Administration 41 (3): 41-65.

Im, T. 2010. Does decentralization reform always increase economic growth?: A cross country comparison of the performance. International Journal of Public Administration 33 (10): 508-520.

Im, T., and W. Cho. 2010. Time factors in policy performance: The Korean government's economic crisis management in 2008. Korean Journal of Policy Studies 25 (2): 103-128.

James, J. 2006. Misguided investments in meeting millennium development goals: A reconsideration using ends-based targets. Third World Quarterly 27 (3): 443-58.

Locke, E. 1996. Motivation through conscious goal setting. Applied and Preventive Psychology 5 (2): 117-24. 
MCST (Ministry of Culture, Sports, and Tourism). 2006. Report on the trend of local festival. MCST.

Okun, L. B. 2004. Fundamental Units: Physics and Metrology. Lecture Notes in Physics 648: 57-74.

Pollitt, C. 2009. Time, policy, management: Governing with the past. New York: Oxford University Press.

Statistics Korea. 2009. Education Statistics. Statistics Korea.

Thiele, R., Nunnenkamp, P., and Dreher, A. 2007. Do donors target aid in line with the Millennium Development Goals? A sector perspective of aid allocation. Review of World Economics 143(4): 596-630.

UNDP (United Nations Development Programme). n.d. What are the Millennium Development Goals? http://www.undp.org/mdg/basics.shtml.

Yang, G. Y. 2006. A research on development of museum facilities with long-term perspective. Korean Research Institution of Culture and Tour. 